\title{
MOLECULAR SCREENING FOR ANAPLASMATACEAE IN TICKS AND TSETSE FLIES FROM ETHIOPIA
}

\author{
Sándor HORNOK ${ }^{1 *}$, Getachew ABICHU ${ }^{2}$, Nóra TAKÁCs ${ }^{1}$, Miklós GYURANECZ, \\ Róbert FARKAS ${ }^{1}$, Isabel G. FERnÁndez De MERA ${ }^{4}$ and José De La Fuente ${ }^{4,5}$ \\ ${ }^{1}$ Department of Parasitology and Zoology, Faculty of Veterinary Science, \\ Szent István University, István u. 2, H-1078 Budapest, Hungary; ${ }^{2}$ National Animal \\ Health Diagnostic and Investigation Center (NAHDIC), Department of Parasitology, \\ Sebeta, Ethiopia; ${ }^{3}$ Institute for Veterinary Medical Research, Centre for Agricultural \\ Research, Hungarian Academy of Sciences, Budapest, Hungary; ${ }^{4}$ SaBio, Instituto de \\ Investigación en Recursos Cinegéticos IREC, CSIC-UCLM-JCCM, Ciudad Real, Spain; \\ ${ }^{5}$ Department of Veterinary Pathobiology, Center for Veterinary Health Sciences, \\ Oklahoma State University, Stillwater, USA
}

(Received 30 June 2015; accepted 28 October 2015)

Hard ticks and tsetse flies are regarded as the most important vectors of disease agents in Sub-Saharan Africa. With the aim of screening these bloodsucking arthropods for vector-borne pathogens belonging to the family Anaplasmataceae in South-Western Ethiopia, four species of tsetse flies (collected by traps) and seven species of ixodid ticks (removed from cattle) were molecularly analysed. DNA was extracted from 296 individual ticks and from 162 individuals or pools of tsetse flies. Besides known vector-pathogen associations, in $\mathrm{Am}$ blyomma cohaerens ticks sequences of Anaplasma marginale and A. phagocytophilum were detected, the latter for the first time in any ticks from cattle in Africa. In addition, part of the gltA gene of Ehrlichia ruminantium was successfully amplified from tsetse flies (Glossina pallidipes). First-time identification of sequences of the above pathogens in certain tick or tsetse fly species may serve as the basis of further epidemiological and transmission studies.

Key words: Anaplasma phagocytophilum, A. marginale, Ehrlichia ruminantium, ticks, tsetse flies, Amblyomma, Glossina

The family Anaplasmataceae includes several pathogenic bacteria, which are of high veterinary and/or medical importance (Dumler et al., 2001). All Anaplasma and Ehrlichia species have their own tissue tropism, and in general they may infect a variety of host cells, primarily those of the peripheral blood and the reticuloendothelial system.

Among the hosts of Anaplasmataceae cattle are particularly important, because these animals may be affected by several members of the family, as exem-

*Corresponding author; E-mail: Hornok.Sandor@aotk.szie.hu; Phone: 0036 (1) 478-4187; Fax: 0036 (1) 478-4193 
HORNOK et al

plified by A. marginale, E. ruminantium and A. phagocytophilum that cause bovine (erythrocytic) anaplasmosis, heartwater and tick-borne fever, respectively. In Ethiopia, where the most important livestock animal is cattle (Leta and Mesele, 2014), A. marginale and E. ruminantium have high veterinary significance, owing to the high abundance of their main tick vectors: Rhipicephalus decoloratus and Amblyomma variegatum, respectively (Pegram et al., 1981). However, the occurrence of $A$. phagocytophilum is unknown in East Africa, in part because its most important vector, Ixodes ricinus can only be found north of the Sahara. Adding to the veterinary significance of A. phagocytophilum, it is regarded as a zoonotic pathogen, albeit its genetic variants from cattle may not cause disease in humans (Zeman and Jahn, 2009). The zoonotic potential of E. ruminantium has also been suggested (Allsopp et al., 2005).

Among Anaplasmataceae the most effective route of transmission to susceptible hosts is by ticks as biological vectors, either transstadially (inoculation by nymphs or adults) or intrastadially by males (Dumler et al., 2001). Some representatives of this family (e.g. A. marginale) may also have alternative ways of spreading between hosts, particularly by blood-sucking flies as mechanical vectors (Kocan et al., 2004).

In the above context, the purpose of this survey was to screen ticks and tsetse flies for the presence of Anaplasma and Ehrlichia spp., and thus to provide new data on the occurrence of these vector-borne pathogens in blood-sucking arthropods. In such an epidemiological study data from Ethiopia may be especially relevant, because it is the second most populated country and has the largest livestock population in Africa (Benin et al., 2006).

\section{Materials and methods}

Samples were obtained in South-Western Ethiopia (Didessa valley, between Nekemte and Jima, coordinates: $09^{\circ} 05^{\prime} \mathrm{N}, 36^{\circ} 33^{\prime} \mathrm{E}-7^{\circ} 40^{\prime} \mathrm{N}, 36^{\circ} 50 \mathrm{E}$ ) in June and July, 2012. Altogether 1032 ixodid ticks were removed from 109 cattle in 18 herds, and identified according to Hoogstraal (1956). Out of these ticks 296 specimens were selected for individual molecular analysis, i.e. one specimen of both sexes or nymphs of each tick species per cattle (118 Amblyomma variegatum, $100 \mathrm{Am}$. cohaerens, 50 Rhipicephalus decoloratus, 17 Rh. praetextatus, 8 Rh. evertsi, $2 \mathrm{Am}$. lepidum and 1 Hyalomma rufipes). Additionally, 601 tsetse flies were collected in the field (at a distance of $\geq 1 \mathrm{~km}$ from cattle herds) with monopyramidal and biconical traps, and identified according to Leak et al. (2008). These were molecularly analysed individually or in pools, i.e. 1-5 specimens according to species, sex and size (sample number: 115 Glossina tachinoides, 32 G. morsitans, 8 G. fuscipes and 7 G. pallidipes). Following me- 
chanical and detergent cleaning, DNA was extracted as described (Hornok et al., 2008), including controls to monitor cross-contamination of samples.

All samples (296 tick and 162 tsetse fly DNA extracts) were preliminarily screened for representatives of the family Anaplasmataceae by a conventional PCR amplifying a 345-bp portion of the $16 S$ rRNA gene and by electrophoresis of the PCR product in a 1.5\% agarose gel (Hornok et al., 2008). Samples (50 tick and 50 tsetse fly DNA) that yielded the strongest band in the gel were further evaluated for the presence of both Anaplasma and Ehrlichia spp., in the following conditions: (1) a 468-bp part of the $16 S$ rRNA gene was amplified with the primers 16SANA-F (5'-CAG AGT TTG ATC CTG GCT CAG AAC G-3') and 16SANA-R (5'-GAG TTT GCC GGG ACT TCT TCT GTA-3'), at an annealing temperature of $42{ }^{\circ} \mathrm{C}$; (2) a 459-bp part of the gltA (citrate synthase) gene was amplified with the primers F1b (5'-GAT CAT GAR CAR AAT GCT TC-3') and HG1085R (5'-ACT ATA CCK GAG TAA AAG TC-3'), at an annealing temperature of $45^{\circ} \mathrm{C}$; (3) a 458 -bp part of the $m s p 5$ (major surface protein 5) gene was amplified with the primers msp5 F (5'-GCA TAG CCT CCG CGT CTT TC-3') and msp5 R (5'-TCC TCG CCT TGG CCC TCA GA-3'), at an annealing temperature of $58{ }^{\circ} \mathrm{C}$; and (4) $1700 \mathrm{bp}$ of the GroEL (chaperone) gene was amplified with the primers EEgro1F (5'-GAG AGA TGC TTA TGG TAA GAC-3') and EEgro2R (5'-CAG CGT CGT TCT TAC TAG GAA-C-3'), at an annealing temperature of $55^{\circ} \mathrm{C}$. Representative sequences were submitted to the GenBank (accession: KM001689-97).

In addition, the presence of $A$. phagocytophilum was evaluated in all tick and tsetse fly DNA extracts by a highly sensitive and specific TaqMan real-time PCR that amplifies part of the $m s p 2$ gene (Courtney et al., 2004). The probe was modified as 6-FAM-TGG TGC CAG GGT TGA GCT TGA GAT TG-TAMRA $\left(5^{\prime}-3^{\prime}\right)$. The assay consisted of 40 cycles, and results were regarded as positive if the threshold cycle $(\mathrm{Ct})$ value was below 39 .

Prevalence rates were analysed with Fisher's exact test. Differences were considered significant when $\mathrm{P}<0.05$.

\section{Results and discussion}

All tsetse fly DNA samples and 95\% (280 out of 296) tick DNA samples were positive in the $16 S$ rRNA PCR. Among the 50 tick samples (i.e. 13 of $\mathrm{Am}$. variegatum, 14 of Am. cohaerens, 22 of Rhipicephalus spp. and one Am. lepidum) and 50 tsetse fly samples (i.e. 39 of G. tachinoides and 11 of other spp.) selected for further analyses, sequencing was successful in the case of 13 (Table 1). In addition, one tick (Am. cohaerens) was shown to contain the sequence of $A$. phagocytophilum with msp2 real-time PCR (Table 1). 
HORNOK et al.

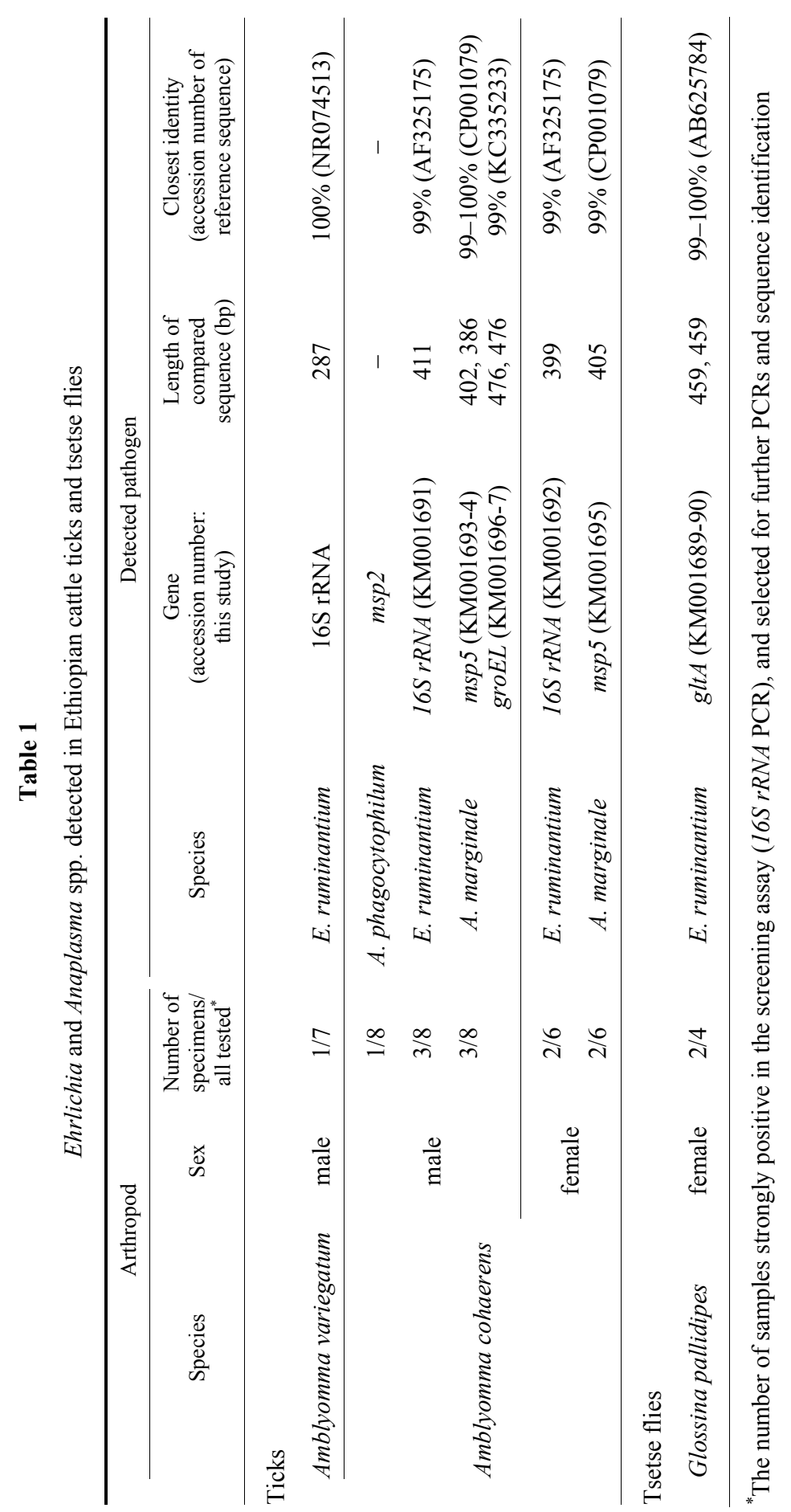


The latter result is the first-time molecular evidence of $A$. phagocytophilum in Am. cohaerens, and altogether in any ticks collected from cattle in Africa. The main vector of this zoonotic pathogen in Europe is the common tick, Ixodes ricinus (which is also indigenous in Africa north of the Sahara, but not in the study region, East Africa). Recently, however, A. phagocytophilum has also been detected in Amblyomma spp., including Am. flavomaculatum collected from West-African savannah monitor lizard (Nowak et al., 2010) and host-seeking Am. americanum in North America (Clark, 2012). The present data broaden the range of Amblyomma spp. which may have access to, or may harbour, A. phagocytophilum.

Sequences of $A$. marginale were identified only in Am. cohaerens (in 5 out of 14 samples: Table 1), to the best of our knowledge for the first time in this tick species. Anaplasma marginale had been reported to have a broad range of competent tick vectors, except for Amblyomma spp. (Kocan et al., 2004). However, recently $A$. marginale has been identified in East-African Am. gemma ticks (Fyumagwa et al., 2009). The present findings confirm the occurrence of $A$. marginale in Amblyomma sp. ticks.

Sequences having the highest similarity to E. ruminantium were identified not only in two of its known tick vector species, Am. variegatum and Am. cohaerens (Table 1), but also in two female Glossina pallidipes individuals, to the best of our knowledge for the first time in any tsetse flies. Because mechanical transmission of E. ruminantium by arthropods has not been verified (Kasari et al., 2010), these preliminary data encourage molecular testing of a broader range of blood-sucking flies in heartwater-endemic countries of Africa.

Based on results of the present study no conclusions can be drawn on the vector competence of relevant arthropods identified here as the source of pathogen-specific DNA. In this context, first-time detection of sequences from Anaplasmataceae in certain tick and tsetse fly species should only be interpreted as the basis or initiative of further epidemiological and transmission studies.

\section{Acknowledgement}

Miklós Gyuranecz and part of the study was supported by the Lendület (Momentum) programme (LP2012-22) of the Hungarian Academy of Sciences.

\section{References}

Allsopp, M. T., Louw, M. and Meyer, E. C. (2005): Ehrlichia ruminantium - an emerging human pathogen. S. Afr. Med. J. 95, 541.

Benin, S., Ehui, S. and Pender, J. (2006): Policies for livestock development in the Ethiopian highlands. In: Pender, J., Place, F. and Ehui, S. (eds) Strategies for Sustainable Land Manage- 
ment in the East African Highlands. International Food Policy Research Institute, Washington, D.C.

Clark, K. L. (2012): Anaplasma phagocytophilum in small mammals and ticks in northeast Florida. J. Vector Ecol. 37, 262-268.

Courtney, J. W., Kostelnik, L. M., Zeidner, N. S. and Massung, R. F. (2004): Multiplex real-time PCR for detection of Anaplasma phagocytophilum and Borrelia burgdorferi. J. Clin. Microbiol. 42, 3164-3168.

Dumler, J. S., Barbet, A. F., Bekker, C. P., Dasch, G. A., Palmer, G. H., Ray, S. C., Rikihisa, Y. and Rurangirwa, F. R. (2001): Reorganization of genera in the families Rickettsiaceae and Anaplasmataceae in the order Rickettsiales: unification of some species of Ehrlichia with Anaplasma, Cowdria with Ehrlichia and Ehrlichia with Neorickettsia, descriptions of six new species combinations and designation of Ehrlichia equi and 'HGE agent' as subjective synonyms of Ehrlichia phagocytophila. Int. J. Syst. Evol. Microbiol. 51, 2145-2165.

Fyumagwa, R. D., Simmler, P., Meli, M. L., Hoare, R., Hofmann-Lehmann, R. and Lutz, H. (2009): Prevalence of Anaplasma marginale in different tick species from Ngorongoro Crater, Tanzania. Vet. Parasitol. 161, 154-157.

Hoogstraal, H. (1956): African Ixodoidea. 1. Ticks of the Sudan with Special Reference to Equatoria Province and with Preliminary Review of Genera Rhipicephalus, Margaropus and Hyalomma. US Navy, Washington D.C.

Hornok, S., Földvári, G., Elek, V., Naranjo, V., Farkas, R. and de la Fuente, J. (2008): Molecular identification of Anaplasma marginale and rickettsial endosymbionts in blood-sucking flies (Diptera: Tabanidae, Muscidae) and hard ticks (Acari: Ixodidae). Vet. Parasitol. 154, 354-359.

Kasari, T. R., Miller, R. S., James, A. M. and Freier, J. E. (2010): Recognition of the threat of Ehrlichia ruminantium infection in domestic and wild ruminants in the continental United States. J. Am. Vet. Med. Assoc. 237, 520-530.

Kocan, K. M., de la Fuente, J., Blouin, E. F. and Garcia-Garcia, J. C. (2004): Anaplasma marginale (Rickettsiales: Anaplasmataceae): recent advances in defining host-pathogen adaptations of a tick-borne rickettsia. Parasitology 129 Suppl., S285-300.

Leak, S. G. A., Ejigu, D. and Vreysen, M. J. B. (2008): Collection of Entomological Baseline Data for Tsetse Area-wide Integrated Pest Management Programmes. Food and Agriculture Organization of the United Nations, Rome. pp. 15-39.

Leta, S. and Mesele, F. (2014): Spatial analysis of cattle and shoat population in Ethiopia: growth trend, distribution and market access. SpringerPlus 3, 310.

Nowak, M., Cieniuch, S., Stańczak, J. and Siuda, K. (2010): Detection of Anaplasma phagocytophilum in Amblyomma flavomaculatum ticks (Acari: Ixodidae) collected from lizard Varanus exanthematicus imported to Poland. Exp. Appl. Acarol. 51, 363-371.

Pegram, G., Hoogstraal, H. and Wassef, H. P. (1981): Ticks Argasidae, Ixodidea of Ethiopia; Distribution, ecology and host relationship of species infecting livestock. Bull. Entomol. Res. 71, 339-359.

Zeman, P. and Jahn, P. (2009): An entropy-optimized multilocus approach for characterizing the strains of Anaplasma phagocytophilum infecting horses in the Czech Republic. J. Med. Microbiol. 58, 423-429. 